\title{
Pelayanan Tenaga Administrasi Sekolah Urusan Kepegawaian Berbasis Teknologi Informasi Pada SMK Kota Padang
}

\author{
Diah Rahayu ${ }^{1}$, Rusdinal ${ }^{2}$, Nelfia Adi ${ }^{3}$, Hanif Al Kadri ${ }^{4}$ \\ Diah Rahayu ${ }^{1}$, e-mail: diahrahayu.dr@gmail.com \\ Rusdinal 2, e-mail: rusdinal@fip.unp.ac.id \\ Nelfia Adi ${ }^{3}$, e-mail: nelfiaadi@fip.unp.ac.id \\ Hanif Al Kadri ${ }^{4}$, e-mail: : hanifalkadri@fip.unp.ac.id
}

\begin{abstract}
This study intends to determine the service of school administration personnel for information technology-based personnel at SMK in Padang City. This type of research is descriptive quantitative, collecting data using a questionnaire with a Likert scale. This study discusses the service of school administrative personnel for personnel affairs, which can be described based on indicators, namely: 1) awareness in providing services has a value of 4.4 in the good category, 2) the ability to provide services has a value of 4.42 in the good category, 3) means of providing services has a value of 4.49 in the good category. Overall, information technology-based staffing services at SMK in Padang City have a score of 4.45 in the good category.
\end{abstract}

\begin{abstract}
Abstrak
Penelitian ini bermaksud untuk mengetahui pelayanan tenaga administrasi sekolah urusan kepegawaian berbasis teknologi informasi pada SMK se-Kota Padang. Jenis penelitian ini deskriptif kuantitatif, mengumpulkan data menggunakan angket dengan skala likert. Kajian ini membahas tentang pelayanan tenaga administrasi sekolah urusan kepegawaian, dapat dijabarkan berdasarkan indikator, yaitu: 1) kesadaran dalam memberikan pelayan memiliki nilai 4,4 pada kategori baik, 2) kemampuan dalam memberikan pelayanan memiliki nilai 4,42 pada kategori baik, 3) sarana dalam memberikan pelayanan memiliki nilai 4,49 pada kategori baik. Secara keseluruhan pelayanan tenaga administrasi sekolah urusan kepegawaian berbasis teknologi informasi pada SMK se-Kota Padang memiliki nilai 4,45 pada kategori baik.
\end{abstract}

Kata Kunci: pelayanan; tenaga administrasi sekolah; teknologi informasi

How to Cite: Rahayu, Diah, Rusdinal, Nelfia Adi, Hanif Al Kadri. 2021. "Pelayanan Tenaga Administrasi Sekolah Urusan Kepegawaian Berbasis Teknologi Informasi pada SMK se-Kota Padang”. Educational Administration and Leadership, Vol (N): pp. XX-XX, DOI: 10.24036/XXXXXXXXXX-X$\mathrm{XX}$

This is an open access article distributed under the Creative Commons 4.0 Attribution License, which permits unrestricted use, distribution, and reproduction in any medium, provided the original work is properly cited. (C2020 by author.

\section{Pendahuluan}

Sekolah melambangkan tempat yang mana terdapat berbagai kegiatan salah satunya yaitu kegiatan pelayanan publik. Konsumen merupakan salah satu bagian dari publik Konsumen disini diibaratkan sebagai individu dan kelompok yang dilayani, kepala sekolah, guru, dewan guru, dan tenaga edukatif lainnya merupakan bagian dari konsumen.

Sekolah merupakan suatu sistem yang di dalamnya terdapat berbagai sumber-sumber. Salah satu sumber daya yang terdapat di dalam sekolah yaitu sumber daya manusia, sumber daya manusia dinilai sangat penting untuk menggerakan seluruh aktivitas yang akan dilakukan sekolah, terutama dalam melayani kebutuhan warga sekolah.

Sumber daya manusianya yaitu tenaga kependidikan dan pendidik. Salah satu tenaga kependidikan yaitu tenaga administrasi sekolah merupakan tenaga pendidik yang memiliki peran yang berguna untuk meningkatkan kelancaran proses pengajaran yang berlangsung. Berdasarkan (Peraturan Menteri Pendidikan Nasional Nomor 24, 2008) mengenai Standar Tenaga Administrasi Sekolah/Madrasah, mereka tenaga administrasi sekolah meliputi:Kepala Tenaga Administrasi Sekolah; Pelaksana Urusan Administrasi Sekolah/Madrasah, meliputi: Pelaksana Urusan Administrasi Kepegawaian; Keuangan; Sarana Prasarana; Humas; Persuratan atau Kearsipan; Kesiswaan; Kurikulum; Petugas Layanan Khusus. 
Pelaksana urusan administrasi kepegawaian memiliki peranan penting dalam administrasi sekolah. Menurut (Syahril, 2009) administrasi kepegawaian merupakan rangkaian sistem kerjasama dengan memanfaatkan potensi-potensi yang ada dengan baik, kemudian warga sekolah bekerja semaksimal mungkin guna mencapai tujuan pendidikan. Kegiatan dalam administrasi kepegawaian meliputi perencanaan personil, pengadaan personil, pemanfaatan, pengembangan personil, pemberhentian personil dan pensiun.

Berdasarkan hasil wawancara dan pengamatan dari beberapa guru di Sekolah Menengah Kejuruan Negeri Tujuh Padang ditemukan beberapa fenomena yang tidak sesuai dengan yang diharapkan dalam memberikan pelayanan kepada guru, fenomena yang ditemui:

1. kurangnya kesadaran tenaga administrasi sekolah urusan kepegawaian dalam melakukan pelayanan, hal ini dapat ditemui dari kurangnya kesadaran tenaga administrasi sekolah urusan kepegawaian dalam mengelola waktu sehingga pekerjaannya tidak siap tepat waktu.

2. Kurangnya kemampuan tenaga administrasi sekolah urusan kepegawaian dalam menjalankan tugasnya seperti masih terdapatnya kesalahan-kesalahan dalam memberikan jadwal mengajar guru.

3. sarana dalam memberikan pelayanan tidak berfungsi dengan maksimal, dengan dibuktikannya dari mesin printer yang sering rusak.

\section{Metode Penelitian}

Riset ini berjenis deskriptif kuantitatif untuk menggambarkan kondisi yang sebenarnya. (Sugiyono, 2011) riset deskriptif merupakan riset yang dikerjakan guna mengetahui nilai dari variabel mandiri, dari satu variabel atau lebih (independen) tanpa adanya perbandingan. Penelitian ini menggunakan indikator, 1) kesadaran dalam memberikan pelayanan, 2) kemampuan dalam memberikan pelayanan, 3) sarana dalam memberikan pelayanan. Dalam penelitian ini populasinya adalah guru sebagai pemakai layanan urusan kepegawaian di 20 SMK se-Kota Padang yaitu 1.158 guru. Sampel ditentukan berdasarkan: bila populasi keseluruhan tidak mencapai 100 maka semuanya dimasukan, namun bila total populasinya besar, boleh digunakan antara 10-15\% atau 20-25\% atau lebih, maka besar sampel penelitian menggunakan kesalahan $10 \%$ dan kepercayaan $90 \%$ kepada populasi berjumlah 99 orang guru. Dalam kajian ini menggunakan angket skala likert dan menggunakan 5 alternatif jawaban yang sudah diuji validitas dan reliabilitas dengan menggunakan SPSS.

\section{Hasil dan Pembahasan}

\subsection{Hasil}

Hasil dari pengolahan data mengenai pelayanan tenaga administrasi sekolah urusan kepegawaian berbasis teknologi informasi pada SMK se-Kota Padang ditinjau dari kesadaran dalam memberikan pelayanan. Skor tertinggi terdapat pada pada item pernyataan tenaga administrasi sekolah urusan kepegawaian mampu melayani kebutuhan guru secara cermat dengan menggunakan teknologi informasi dengan perolehan skor 4,52 berada pada kategori baik. Sedangkan tingkat capaian terendah yaitu tenaga administrasi sekolah urusan kepegawaian bertanggung jawab atas kesalahan dalam menggunakan teknologi informasi dengan skor 4,35 pada kategori baik.

Hasil pengolahan data ditinjau dari kemampuan dalam memberikan pelayanan capaian tertinggi yaitu tenaga administrasi sekolah urusan kepegawaian memiliki integritas dan akhlak mulia dalam memberikan pelayanan berbasis teknologi informasi, dengan skor 4,55 pada kategori baik. Sedangkan tingkat capaian terendah terdapat yaitu tenaga administrasi sekolah urusan kepegawaian mampu menilai kinerja staf dengan baik dengan menggunakan teknologi informasi dengan skor 4,27 pada kategori baik.

Hasil pengolahan data mengenai pelayanan tenaga administrasi sekolah urusan kepegawaian berbasis teknologi informasi pada SMK se-Kota Padang ditinjau dari sarana dalam memberikan pelayanan bahwa tingkat capaian tertinggi yaitu tenaga administrasi sekolah urusan kepegawaian dalam mengelola data guru menggunakan teknologi informasi seperti Ms.Excel, dengan skor 4,55 kategori baik. Sedangkan tingkat capaian terendah yaitu tenaga administrasi sekolah urusan kepegawaian memiliki fasilitas seperti mesin pendingin ruangan dan mesin absensi dalam memberikan pelayanan berbasis teknologi informasi dengan skor 4,43 kategori baik.

\subsection{Pembahasan}

Secara umum pelayanan tenaga administrasi sekolah urusan kepegawaian di SMK se-Kota Padang dilihat dari kesadaran memberikan pelayanan dengan kategori baik dengan perolehan 4,44. Ini menunjukan bahwa pelayanan tenaga administrasi sekolah urusan kepegawaian berbasis teknologi informasi sudah dilakukan dengan baik, namun perlu untuk dipertahankan dan ditingkatkan lagi. Beberapa upaya meningkatkan kesadaran pelayanan tenaga administrasi sekolah urusan kepegawaian yaitu tenaga administrasi sekolah urusan kepegawaian dalam bekerja harus ikhlas dan bersungguh-sungguh ketika mengerjakan atau melaksanakan suatu kemauan, karena kemauan dalam organisasi kerja merupakan bentuk dari tugas,baik secara tertulis maupun tidak. 
Cara lainnya yaitu dengan memotivasi tenaga administrasi sekolah urusan kepegawaian dalam memberikan pelayanan yang baik. Motivasi menurut (Hikmat, 2011) adalah dorongan yang diberikan kepada seseorang agar mempunyai kemauan untuk mengerjakan sesuatu. Dorongan ini bisa dikerjakan dengan berbagai tindakan, contohnya yaitu meninggikan upah atau bayaran kerja, imbalan dan reward, aturan-aturan dan sanksi yang ketat bagi yang melanggarnya.

Berdasarkan hasil penelitian menunjukan kemampuan pelayanan tenaga administrasi sekolah urusan kepegawaian pada SMK se-Kota Padang pada kategori baik dengan total 4,43. Ini menunjukan bahwa kemampuan pelayanan tenaga administrasi sekolah urusan kepegawaian sudah dilakukan dengan baik.namun perlu untuk dipertahankan dan ditingkatkan lagi. Beberapa upaya yang dapat dilakukan guna meningkatkan kemampuan pelayanan oleh tenaga administrasi sekolah yang baik yaitu dengan melakukan pembinaan dan pengembangan tenaga kependidikan.

Menurut (Mustrasi, 2015) pembinaan atau pengembangan suatu upaya memberdayakan, meningkatkan serta memajukan,hasil kerja pada tenaga kepegawaian saat berada pada jenjang pendidikan dan seluruh tingkatan manajemen organisasi. Adapun cara yang digunakan dalam pengembangan pegawai:

Berdasarkan hasil penelitian menunjukan sarana pelayanan tenaga administrasi sekolah urusan kepegawaian kategori baik dengan jumlah 4,49. Ini menunjukan bahwa sarana yang digunakan dalam memberikan pelayanan berbasis teknologi informasi sudah baik namun perlu ditingkatkan lagi. Upaya yang dapat dilakukan yaitu melakukan pemeliharaan terhadap sarana yang digunakan dalam bekerja. menjaga kebersihan sarana dalam melaksanakan tugas dan menyimpan dengan baik sarana yang digunakan sesudah melakukan tugas atau pekerjaan.

Menurut (Gunawan, 2002) aktivitas pemeliharaan bisa dikerjakan berdasarkan jangka waktu dan berdasarkan kondisi keadaan barang. Pemeliharaan berdasarkan jangka waktu bisa dikerjakan setiap hari (sesudah/setiap akan menggunakan) dan berkelanjutan selama kurun tenggang waktu tertentu berdasarkan arahan penggunaan. Pemeliharaan barang yang dikerjakan berdasarkan kondisi peralatannya dilakukan terhadap peralatan habis pakai dan peralatan tidak habis pakai, pemeliharaan kertas dan sebagainya dengan penyimpanan yang bagus (bebas hama, aman, tidak lembab), sebelum peralatan digunakan atau dalam penyimpanan. Terhadap peralatan tidak habis dipakai seperti komputer, printer dikerjakan perbaikan apabila kondisi penggunaannya tidak lagi berfungsi.

\section{Kesimpulan}

Berdasarkan penelitian yang telah dikemukakan sebelumnya, mengenai pelayanan tenaga administrasi sekolah urusan kepegawaian berbasis teknologi informasi pada SMK se-Kota Padang.

1. Pelayanan tenaga administrasi sekolah urusan kepegawaian berbasis teknologi informasi ditinjau dari kesadaran dalam memberikan pelayanan berada pada kategori baik, dengan skor 4,44.

2. Pelayanan tenaga administrasi sekolah urusan kepegawaian berbasis teknologi informasi ditinjau dari kemampuan dalam memberikan pelayanan berada pada kategori baik, dengan skor 4,42.

3. Pelayanan tenaga administrasi sekolah urusan kepegawaian berbasis teknologi informasi ditinjau dari sarana dalam memberikan pelayanan berada pada kategori baik, dengan tingkat capaian 4,49.

\section{Daftar Rujukan}

Gunawan. (2002). Administrasi Sekolah. Jakarta: Rineka Cipta.

Hikmat. (2011). Manajemen Pendidikan. Bandung: Pustaka Setia.

Mustrasi, M. (2015). Manajemen Pendidikan. Jakarta: Raja Grafindo.

Peraturan Menteri Pendidikan Nasional Nomor 24. tentang Standar Tenaga Administrasi Sekolah/Madrasah (2008). Indonesia.

Sugiyono. (2011). Metode Penelitian Kuantitatif dan Kualitatif. Bandung: Alfabeta.

Syahril. (2009). Profesi Kependidikan. Padang: UNP Press. 